\title{
Socio-economic status of the farmers and economic analysis of poultry farming at Gazipur district in Bangladesh
}

\author{
Alam $\mathrm{M}^{1}$, Sultana $\mathrm{S}^{2}$, Hassan $\mathrm{MM}^{3}$, Hasanuzzaman $\mathrm{M}^{1}$, Faruk $\mathrm{MSA}^{3}$ \\ ${ }^{1}$ Department of Animal Science \& Nutrition, ${ }^{2}$ Department of Agricultural Economics and Social Sciences, \\ ${ }^{3}$ Department of Physiology, Biochemistry and Pharmacology; Faculty of Veterinary Medicine, Chittagong \\ Veterinary and Animal Sciences University, Khulshi, Chittagong-4225, Bangladesh
}

[Received: June 15, Accepted: July 20, 2014].

\begin{abstract}
The study was conducted to identify the socio-economic status of the poultry farmers and economic analysis of poultry farming at Gazipur, Bangladesh. A Total of 40 poultry farms (20 broilers and 20 layers) were selected. The farmers and farming were evaluated through the analysis of data that were collected in a pre-structured questionnaire. This study revealed that comparatively rich farmers $(42.5 \%$ had $>4.94$ acre of land) were involved in farming. There were significant variations ( $\mathrm{p}<0.05)$ in source of investment $(57.5 \%$ own, 32.5\% bank loan, $7.5 \%$ from money lenders with interest and 5\% from money lenders without interest), training (72.5\% not received and $27.5 \%$ received), farming as an occupation for the farmers (55\% main and $45 \%$ subsidiary occupation), amount of loan taken (50\% have loan and $50 \%$ have no loan), level of educational knowledge (62.5\% poor, $25 \%$ medium and $23.5 \%$ high), sources of drinking water ( $87.5 \%$ have own tubewell), latrine condition ( $67.5 \%$ have sanitary latrine) and health status of the farmers (30\% good, $50 \%$ medium and $20 \%$ poor). There were no significant variation $(\mathrm{p}>0.05)$ in farm size and management skills of the farmers. The average number of children per farmer attends to primary school, high school, college and university were $0.7,0.75,0.1$ and 0.01 in case of boys and $0.5,0.45,0.07$ and 0.01 in case of girls, respectively. Per bird average annual rearing cost, return, and cost benefit ratio were 925.5 BDT., 1080 BDT. and 1:1.17 in broiler and 1332.5 BDT., 2210 BDT. and 1:1.66 in layer, respectively. This study recommends although initial investment is higher; layer farming is more profitable than broiler.

Key words: Poultry farming, Socio-economic condition, Management, Cost Benefit Ratio
\end{abstract}

\section{INTRODUCTION}

The people of Bangladesh are blessed with a variety of agricultural resources of which chicken rearing is considered to have potential both for poverty alleviation and food production ${ }^{[1]}$. Chicken rearing is suitable for widespread implementation as it requires less cost, little skills and is highly productive and can be incorporated into the household works ${ }^{[2]}$. In the last few years, the credit of small-scale commercial poultry production helps to quicken the pace of poverty reduction riding in new altitude in Bangladesh. The poultry industry has been magnificently becoming a prominent industry of the country. This industry has immense potentialities from the point of view of the economic growth of the country as well as fulfillment of basic needs and to keep the price at a minimum level and ensuring food especially animal protein for the human being. This industry has immense scope for the country through changing livelihood and food habit, reduction of dependence of meat related to cow and goat and ultimately has positive impact on GDP growth rate of the country ${ }^{[3]}$. The overall socio-economic condition of the beneficiaries, their egg and meat intake ability, empowerment of rural women in decision making and employment opportunities were significantly increased by rearing poultry after the intervention made by Smallholder Livestock Development Project (SLDP) ${ }^{[4]}$. Study showed that commercial broiler farming provided employment opportunities for unemployed family persons, developed socio- economic conditions and increased women empowerment among rural people of Bangladesh ${ }^{[5]}$. Poultry farming has been playing a key role in providing meat to overcome the malnutrition and serve as a tool for employment generation and poverty alleviation ${ }^{[6]}$. The district Gazipur occupies an important place in Bangladesh in respect of poultry farming because of availability of all facilities. It is called the poultry belt of Bangladesh. So, the present study was undertaken to identify the socio-economic status of the poultry farmers and economic analysis of poultry farming (broiler and layer) in Gazipur district of Bangladesh.

\section{MATERIALS AND METHODS}

\section{Study area and Period of study}

The study was conducted at Gazipur district in Bangladesh between the periods of 16 July, 2012 to 7 September, 2012. The geographical location of Gazipur district is $25^{\circ} 15^{\prime} 0^{\prime \prime} \mathrm{N}$ (North) and $89^{\circ} 30^{\prime} 0^{\prime \prime} \mathrm{E}$ (East) in DMS (Degrees Minutes Seconds).

Sources of data

Data for this study was obtained from both primary and secondary sources. The primary data were collected from the poultry farmer using structured questionnaires. The secondary data were obtained from District livestock office.

Research design 
The research design adopted for this study was of expost-facto in nature since the phenomenon has already occurred ${ }^{[7]}$.

Population and sample size

All the poultry farms of the district engaged in poultry production were considered as population and a sample size of 40 (20 broiler and 20 layer farms) poultry farms were selected.

Sampling methods

Gazipur district and Kaliganj upazila were selected in bias (Non-random selection). Kaliganj upazila has eight unions. From these unions' five unions was randomly selected and from these five unions' two villages from each union was randomly selected (Multi-stage random sampling). From these selected villages two farms of each category (Broiler and Layer) were selected randomly (Stratified random sampling). Each farm rearing at least 1000 bird is taken under consideration.

Methods of data collection
Data were collected through direct interview schedule and recorded in a questionnaire. The schedule was prepared maintaining relevance with the objectives of the study. Before launching the survey, the questionnaire was pre-tested and improved accordingly. In order to collect the more purified data of various farms an organized questionnaire was formatted ${ }^{[8]}$.

Analytical techniques

The data were put on the master sheet in Microsoft Office Excel 2007 and were arranged in tabular form. The obtained data imported to software STATA/IC-11.0 for analysis. The comparisons of variables with different categories were done by using Epi info software version 7.1.3.0.

\section{RESULTS AND DISCUSSION}

Socio-economic status of the farmers

Different variables and categories used to describe

\begin{tabular}{|c|c|c|c|c|c|}
\hline Variables & Categories & $\begin{array}{l}\text { No. of farm/ } \\
\text { Farm owner }\end{array}$ & $\begin{array}{l}\text { Percentage } \\
(\%)\end{array}$ & $\begin{array}{l}x^{2}- \\
\text { Value }\end{array}$ & $\begin{array}{l}\mathrm{p}- \\
\text { value }\end{array}$ \\
\hline \multirow{5}{*}{ Type of farmer } & Landless (0.00-0.50 acre) & 2 & 5 & \multirow[t]{5}{*}{27.5} & \multirow[t]{5}{*}{0.00} \\
\hline & Marginal (0.51-1.24 acre) & 3 & 7.5 & & \\
\hline & Small (1.25-2.47 acre) & 5 & 12.5 & & \\
\hline & Medium (2.48-4.94 acre) & 13 & 32.5 & & \\
\hline & Large $(\geq 4.95$ acre $)$ & 17 & 42.5 & & \\
\hline \multirow[t]{4}{*}{ Investment source } & Own & 23 & 57.5 & \multirow[t]{4}{*}{41.07} & \multirow[t]{4}{*}{0.00} \\
\hline & Bank loan & 13 & 32.5 & & \\
\hline & $\begin{array}{l}\text { With interest from money } \\
\text { lender }\end{array}$ & 3 & 7.5 & & \\
\hline & $\begin{array}{l}\text { Without interest from money } \\
\text { lender }\end{array}$ & 1 & 2.5 & & \\
\hline \multirow{3}{*}{$\begin{array}{l}\text { Size of the farm (No. } \\
\text { of birds) }\end{array}$} & $<3000$ & 10 & 25 & \multirow[t]{3}{*}{3.9} & \multirow[t]{3}{*}{0.14} \\
\hline & $3000-5000$ & 18 & 45 & & \\
\hline & $>5000$ & 12 & 30 & & \\
\hline \multirow[t]{2}{*}{ Training } & Yes & 11 & 27.5 & \multirow[t]{2}{*}{16.2} & \multirow[t]{2}{*}{0.00} \\
\hline & No & 29 & 72.5 & & \\
\hline \multirow[t]{2}{*}{ Family Type } & Single & 19 & 47.5 & \multirow[t]{2}{*}{0.2} & \multirow[t]{2}{*}{0.65} \\
\hline & Joint & 21 & 52.5 & & \\
\hline \multirow{2}{*}{$\begin{array}{l}\text { Farming as main } \\
\text { occupation }\end{array}$} & Yes & 22 & 55 & \multirow[t]{2}{*}{0.8} & \multirow[t]{2}{*}{0.37} \\
\hline & No & 18 & 45 & & \\
\hline \multirow{4}{*}{$\begin{array}{l}\text { Amount of loan } \\
\text { (BDT.) }\end{array}$} & No loan & 20 & 50 & \multirow[t]{4}{*}{18.93} & \multirow[t]{4}{*}{0.00} \\
\hline & $<100000$ & 5 & 12.5 & & \\
\hline & $100000-500000$ & 9 & 22.5 & & \\
\hline & $>500000$ & 6 & 15 & & \\
\hline \multirow[t]{3}{*}{ Education } & High ( Above secondary) & 5 & 12.5 & \multirow[t]{3}{*}{24.38} & \multirow[t]{3}{*}{0.00} \\
\hline & Medium (Secondary) & 10 & 25 & & \\
\hline & Poor ( Primary) & 25 & 62.5 & & \\
\hline \multirow{3}{*}{$\begin{array}{l}\text { Poultry farm } \\
\text { management skill }\end{array}$} & High & 15 & 37.5 & \multirow[t]{3}{*}{1.88} & \multirow[t]{3}{*}{0.39} \\
\hline & Medium & 15 & 37.5 & & \\
\hline & Poor & 10 & 25 & & \\
\hline Source of drinking & Own tube-well & 35 & 87.5 & 79.27 & 0.00 \\
\hline water & Shared-in tube-well & 2 & 5 & & \\
\hline & Shared-in deep tube-well & 3 & 7.5 & & \\
\hline Condition of latrines & Non-sanitary & 0 & 0 & 43.69 & 0.00 \\
\hline & Semi-sanitary & 10 & 25 & & \\
\hline & Sanitary & 27 & 67.5 & & \\
\hline Health status & Good & 12 & 30 & 8.4 & 0.01 \\
\hline & Moderate & 20 & 50 & & \\
\hline & Poor & 8 & 20 & & \\
\hline
\end{tabular}


socio-economic status of the farmers are enlisted in Table 1. There was highly significant $(p<0.01)$ variation among the farmers in terms of amount of land. About $42.5 \%$ large, $32.5 \%$ medium, $12.5 \%$ small, $7.5 \%$ marginal and $5 \%$ landless farmers were involved in farming. These findings agree with the

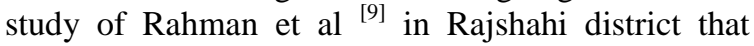
indicate that comparatively rich farmers are more involved than poor, although Islam et al ${ }^{[10]}$ reported that all of the farmers involved in the farming were small categories (Having 6-49 decimal land) in a study on broiler farming in Bangladesh. The sources of investments for the farmers were highly varied $(p<0.01)$. Most of the farmer $(75 \%)$ manages investment from money lender in terms of interest, $57.5 \%$ farmer invests their own money in farming, $32.5 \%$ takes bank loan and remaining $2.5 \%$ takes loan from money lender but without interest. These findings have similarity with Rahman et al ${ }^{[9]}$ in a study in Rajshahi district of Bangladesh. There were no significant different $(p>0.05)$ in terms of size of the farms. About $25 \%$ of the farmers have less than 3000 birds, $45 \%$ have 3000-5000 birds and 30\% have more than 5000 birds. Only a small proportion $(27.5 \%)$ of the farmers had received training on poultry farming in comparison to $(p<0.01)$ those did not have received $(72.5 \%)$. The present study shows that, farming was the main occupation of $55 \%$ of the farmers and for remaining $45 \%$, it is subsidiary occupation. Ahmed et al ${ }^{[3]}$ showed that, farming is the main occupation of the $35 \%$ of the broiler farmer. This higher value in current finding is due to involvement of layer farms but Ahmed et al ${ }^{[3]}$ did not consider layer farmers. There was highly significant $(p<0.01)$ variation among the farmer's in terms of amount of loan taken. About $12.5 \%$ of the farmers have loan less than BDT. 100,000, 22.5\% farmers have loan between BDT. 100,000-500,000, $15 \%$ have more than BDT. 500,000 and $50 \%$ of the farmers have no loan. The level of educational knowledge among the farmers was differing very significantly $(p<0.01)$. Most of the farmers have poor level of knowledge $(62.5 \%)$. Rahman et al ${ }^{[9]}$ found that, $71.43 \%$ and $24.29 \%$ of the farmers have high and medium level of knowledge respectively. Sumy et al ${ }^{[1]}$ reported more or less similar findings of literacy level of the farmers in a study on backyard chicken owners in Pabna district. There was no significant difference $(p>0.05)$ in management skill
(37.5\% High, $37.5 \%$ medium and $25 \%$ poor) among the farmers. There were highly significant variation $(P<0.01)$ in sources of drinking water and latrine condition of the farmers. Most of the farmer had own tube-well $(87.5 \%)$ and most of them were use sanitary latrine $(67.5 \%)$. The shearing of tube well $(5 \%)$ is restricted to some drought months only. Ahmed et al ${ }^{[3]}$ showed using of higher percentage of semi-sanitary latrine among the farmer. There were observed significant variation $(p<0.05)$ in health status among the farmers. In terms of health status there revealed that about $30 \%$ of the farmers had good health, $50 \%$ and $20 \%$ had moderate and poor health, respectively.

The level of education of the farmer's children reflects the socio-economic position of a family in a society. The average number of children per farmer attends to primary school; high school, college and university were $0.7,0.75,0.1$ and 0.01 in case of boys and $0.5,0.45,0.07$ and 0.01 in case of girls, respectively (Table 2). These findings of the study in agreement with Ahmed et al ${ }^{[3]}$ they also found more or less similar educational status.

Figure 1: Gross return, gross cost and net profit of per broiler and layer birds.

\section{Economic analysis}

Annual average gross cost of rearing per layer and six broilers (In 6 batches in a year) were 925.5 BDT. and 1332.5 BDT., respectively (Table 3 ).

In a study on economic analysis of poultry farms of different sizes in some selected area of Dhaka district, Islam and Jabbar ${ }^{[11]}$ found that the total costs of rearing per poultry bird per year were BDT. 406.17, 373.86 and 347.54 for small, medium and large poultry farms, respectively. Alam ${ }^{[4]}$ found the cost per bird was BDT. 106.68 in intensive farm. The higher value of cost in current study is due to recent increase of price of feed and other raw materials. Per bird gross return of broiler and layer are shown in the Table 4. Per bird gross return of broiler and layer are BDT. 1080 and BDT. 2210, respectively which is higher than per bird net cost. Islam and Jabbar ${ }^{[11]}$ found average gross return per poultry bird per year stood at BDT. 614.15, 599.67 and 351.69 for small, medium and large farm, respectively. Alam ${ }^{[4]}$ found the return per bird was BDT. 129.5 in intensive farm. The higher value of return in current study is due to recent increase of price of chicken meat and eggs.

Table 2: Distribution of children of farmers by institute $(\mathrm{N}=40)$

\begin{tabular}{ccc}
\hline Particulars & Average no. of boys/farmer's family & Average no. of girls/farmer's family \\
\hline Primary & 0.7 & 0.5 \\
High school & 0.75 & 0.45 \\
College & 0.10 & 0.07 \\
University & 0.01 & 0.01
\end{tabular}


Table 3: Per bird annual gross cost (Average)

Items Expenditure

\begin{tabular}{|c|c|c|c|c|c|c|}
\hline & \multicolumn{2}{|c|}{ Per bird cost in one batch } & \multirow{2}{*}{$\begin{array}{l}\text { Total cost } \\
\text { (BDT.) }\end{array}$} & \multicolumn{2}{|c|}{ Per bird annual cost } & \multirow{2}{*}{$\begin{array}{l}\text { Total } \\
\text { cost } \\
\text { (BDT.) }\end{array}$} \\
\hline & $\begin{array}{l}\text { Gross } \\
\text { Cost (BDT.) }\end{array}$ & $\begin{array}{l}\text { Depreciation } \\
\text { cost (BDT.) }\end{array}$ & & $\begin{array}{l}\text { Gross } \\
\text { cost (BDT.) }\end{array}$ & $\begin{array}{l}\text { Depreciation } \\
\text { cost (BDT.) }\end{array}$ & \\
\hline DOC & 45 & - & 55 & 50 & - & 50 \\
\hline Feed & 81 & - & 81 & 1259 & - & 1259 \\
\hline Labor & 8 & - & 8 & 10 & - & 10 \\
\hline Medication & 8 & - & 8 & 10 & - & 10 \\
\hline Housing & - & 2 & 2 & - & 3.00 & 3 \\
\hline Equipment & - & 0.25 & 0.25 & - & 0.50 & 0.5 \\
\hline $\begin{array}{l}\text { Total gross } \\
\text { cost }\end{array}$ & 142 & 2.25 & 154.25 & 1329 & 3.50 & 1332.5 \\
\hline Total gross ce & t for 6 batch $i$ & rear: $154.25 *$ & 25.5 & & & \\
\hline
\end{tabular}

Table 4: Per bird annual gross return and cost benefit ratio (Average)

\begin{tabular}{lll}
\hline Items & Broiler (BDT.) & Layer (BDT.) \\
\hline Selling of bird (6 broiler/1 spend layer hen) & 1080 & 180 \\
Selling of eggs (290 pieces) & - & 2030 \\
Total gross return & 1080 & 2210 \\
Per bird annual cost benefit ratio (Annual per & $1: 1.17$ & $1: 1.66$ \\
bird total gross return * Annual per bird total & & \\
gross cost) & & \\
\end{tabular}

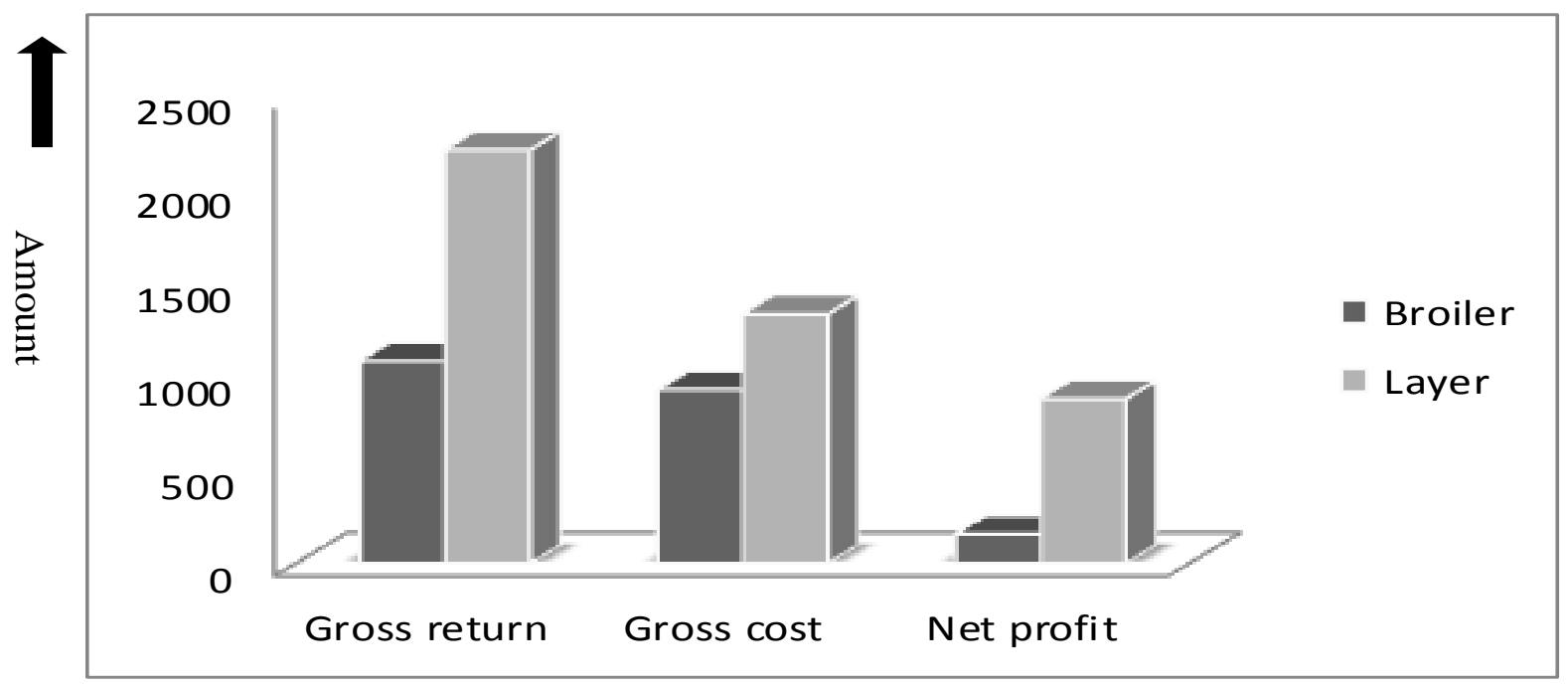

Figure 1: Gross return, gross cost and net profit of per broiler and layer birds.

The figure 1 shows that gross return, gross cost and net profit is higher in layer than broiler. This indicates that although rearing cost is high in layer farm but it is more profitable than broiler farming. The result of cost benefit ratio is 1: 1.17 in broiler and 1: 1.66 in layer (Table 4). The cost benefit ratio value in current study is more or less close to the findings of Alam ${ }^{[4]}$, who found 1: 1.22 cost benefit ratio for intensive farms.

\section{CONCLUSION}

Poultry farming is a great opportunity for the rural people and youth as a means of income generation. The socioeconomic status of the farmers of Gazipur district was found variable in current study. Comparatively rich farmers were involved in farming. There were variations in source of investment, training, farming as an occupation for the farmers, amount of loan taken, level of 
educational knowledge, sources of drinking water, latrine condition and health status of the farmers, but no variation were observed in farm size and management skills of the farmers. In economic analysis the layer farming was found more profitable. This study recommends the farmers to establish layer farm for more profit.

\section{REFERENCES}

1. Sumy MC, Khokon, MSI, Islam MM and Talukder S (2010). Study on the socioeconomic condition and productive performances of backyard chicken in some selected areas of Pabna district. J. Bangladesh Agril. Univ. 8(1): 45-50.

2. Dolberg F, Jensen HA, Sorensen P and Rahman M (1997). Exotic hens under semi scavenging conditions in Bangladesh. Livestock Res. Rural Devel. 9(3).

3. Ahmed JU, Mozumdar L, Farid KS and Rahman MW (2009). Broiler farming: An approach to improve rural livelihood. $J$. Bangladesh Agril. Univ. 7(2): 395-402.

4. Alam J (1997). Impact of smallholder livestock development project in some selected areas of rural Bangladesh. Livestock Res. Rural Devel. 9(3).

5. Rahman SMA, Sayeed MA, Sarker, NR and Alam J (2006). Impact of improved poultry management technique on socio-economic condition of broiler beneficiaries. $J$. Bangladesh Agril. Univ. 4 (2): 401-411.

6. Raha SK (2007). "Broiler industry in Bangladesh: some issues". Proceedings of the fifth International Poultry Show and Seminar, Organized by World's Poultry Science Association, Bangladesh Branch, Dhaka, Bangladesh.

7. Sevilla CG, Ochave JA, Punsalan TG, Regala BP and Uriarte GG (2007). Research methods. 3rd end, Rex book store.

8. Nauta WJ, Baars T, Groen AF, Veerkamp, RF and Roep D (2001). Animal Breeding in Organic Farming.Discussion paper, Louis Bolk Institute, Driebergen.

9. Rahman MM, Islam MR, Ullah $\mathrm{MN}$, and Adeyl FMM (2002). Study on the Scientific Knowledge and Managemental Skill in Commercial Broiler Farming Programme at the Farmers Level of Rajshahi District. OnLine J. Biol. Sci. 2(11): 767- 768.

10. Islam MS, Takashi $\mathrm{S}$ and Chhabi KQN (2010). Current Scenario of the Small-scale Broiler Farming in Bangladesh: Potentials for the Future Projection. Inter. J. Poultry Sci. 9 (5): 440-445.

11. Islam SMF and Jabbar MA (2005). Smallholder poultry model for poverty alleviation in Bangladesh: A review of evidence on impact. Livestock Res. Rural Devel.17(10). 